International Journal of Social Science and Economic Research

ISSN: $2455-8834$

Volume: 05, Issue: 07 "July 2020"

\title{
INCOME INEQUALITY, SAVING LEVEL AND ECONOMIC GROWTH IN UAE
}

\author{
${ }^{1}$ Bibi Fatimah Shir Agha, ${ }^{2}$ Omaima Ahmed, ${ }^{3}$ Maryam Mohammed Alfarji, ${ }^{4}$ Misbah Sadiq \\ 1,2,3,4 Al Qasimia University, Sharjah, UAE
}

DOI: 10.46609/IJSSER.2020.v05i07.001 URL: https://doi.org/10.46609/IJSSER.2020.v05i07.001

\begin{abstract}
This study investigates the impact of income inequality on the economic growth through mediating role of saving level. It gives a breakdown of overall income inequality by gender, age, education, and nationality. Study utilized primary data to measure the set objectives. The findings confirm that although overall income inequality is relatively low based on the gender differences, spearman correlation analysis signifies sizeable disparity in income distribution by level of age, education and nationality. Nationality is found to be the most significant inequalityincreasing factor followed by level of education and age and people with high income tend to save more. Furthermore, positive relationship has been approved between income inequality and saving behavior thus economic growth of the country. In addition, saving account comes as the most preferred mode for $\mathrm{UAE}$ residents to save their money, and real estate sector is the main driver of economic growth in UAE.
\end{abstract}

Keywords: Gender, age, education, nationality, income inequality, saving level and economic growth and UAE

\section{INTRODUCTION}

Why income inequality is an important issue in recent decades? And how is it related to economic growth? The idea of income inequality and saving behavior is not new. The concept of income is very simple and most fundamental in Economics. It refers to the amount of money in a given period of time, which individual can spend in consumption without changing the value of his wealth. But what does income inequality mean? Income inequality is the gap between the richest and the rest. It means extreme concentration of wealth or income in few hands. It is a multidimensional concept. In other words, the degree of income that distributed unequally in economy or population. By using Gini coefficient and Lorenz Curve to be illustrated. 


\section{International Journal of Social Science and Economic Research}

ISSN: $2455-8834$

Volume: 05, Issue: 07 "July 2020"

According to Keynes (1939), saving is the excess of income over what person spends on consumption or the portion of disposal income after consumption of consumer goods. It is a normal fact that when people save more, the level of disposal income will increase as well as the living standard of people. Even more, saving means different things like putting money in the bank or buying stocks. Economists define saving as consuming less in the present to consume more in the future. While economic growth is a rise in income per capita and increase in production of goods and services over specific period. Real GDP is one of the accurate measurements of growth.

One of the most famous theorists was Simon Kuznets, a Russian-American economist. He believed that the gap of income inequality is low in pre-industrial societies. He conducted a research in 1955 and found that the higher degree of inequality was in developing countries while the lower degree of inequality was in rich developed countries. He mentioned that income inequality before taxes has been explained by concentration of savings in the upper income groups. This leading to widen the gap of inequality as result of rapid economic growth in urban societies than agricultural societies.

Ranciere et al. (2012) and Treek (2013) found that there is a transmission in the neoclassical growth literature as a result of positive relationship between income inequality and saving. However, some recent studies suggest a negative link between inequality and saving that could be one reason behind the current account deficits of some countries.

In classical theories, saving considered as a mediating variable in explaining the economic growth process and how this process affects income inequality. Nevertheless, some scholars showed that there is no evidence to prove that saving of high-income groups leads to accelerate the economic growth as it happened in low developed countries (Gallo, 2002)

This relationship between income inequality, saving behavior and economic growth is different. Some researchers believed that income inequality is incentive to economic growth because some society's classes highly tend to save more then to finance the investment that contribute to achieve high economic growth. While others believed that income inequality leads to low income of most population. That means diminishing the aggregate demand as well as slowdown the economic growth (keeley, 2015).

According to many economists, the effects of economic growth on the distribution of income are more complex and are not only a dynamic relationship. As result of that, economists' attention shifted to study the impact of income inequality on saving and economic growth instead of the opposite. 


\section{International Journal of Social Science and Economic Research}

ISSN: $2455-8834$

Volume: 05, Issue: 07 "July 2020"

This study is an attempt to further investigate the impact of income inequality on the economic growth through mediating role of saving behavior. Obviously, it will help policy makers and advisors to shape the structure of any economy in a good way.

\section{LITERATURE REVIEW}

Several studies made with the purpose of understanding the income inequality, its determinants in addition to its relationship with saving level. Jorge A. Charles-Coll. (2011), stated such inequality in the distribution of income may occur through many factors, theoretically some of them linked with it while the others react for the same economic forces. He arranged them into two groups: the endogenous relates to the decisions made by person and the exogenous determents like economic development as well as social policy.

Furceri Davide and Ostry Jonathan D.(2019) , also agreed the previous study and state that, based on the WALS (weighted-average least squares) model that they used to get the strongest determinants of the income inequality, they found that the development grade, demographics, unemployment, globalization, as well as technological change are the factors that drive more inequality, and they suggest that financial deregulation and technological change are main reasons behind the high income inequality, mostly in economies which are more promoted.

A high increase in the degree of income inequality is one of the most recent problems that are faced within the whole world especially in rich countries and are still being argued upon this issue, taking into account the role of globalization against technology and of market forces against institutions and policy choices. Nolan, Brian, et al. (2019).

As another determinant for the unequal distribution of income Keller, Katarina R. I. (2010), added that the cost that be paid per student in the basic education can highly enhance income distribution particularly globally and for countries which are less developed. So the inequality in the income of the households has been approved with its determinants. In order to reach the objectives of this paper, evidences on the relationship between income inequality and saving rates should be provided.

The analysis on the effect of income inequality on saving rates to 1950s with Kaldor (1957), Lewis (1954), Passinetti (1962) as some of the initial studies. Kaldor (1957) and Lewis (1954) state a positive relationship between income inequality and saving rate based on that workers do not save because they earn at subsistence level while entrepreneurs would save more.

Francisco Alvarez-Cuadrado and Mayssun El-Attar Vilalta. (2012), state that in case of permanent income the rate of saving will increase and after prevailing of the income they found that saving rate declined. 


\section{International Journal of Social Science and Economic Research}

ISSN: $2455-8834$

Volume: 05, Issue: 07 "July 2020"

Alan, Sule, et al. (2015), showed that whether the high income Canadian families do save more than poor families and their answer was yes, saving rates is not going to highly change between those who earn high in the long-run income. They approved that there are no strong differences between savings of middle and high income households but for the poorest class which has the lowest income they do not save as they spend all their income on their expenses. They reject the idea that says high income people do save much more than others by equalizing the upper class with the middle one.

Koo, Jaewoon and Song, Yunxing (2016), confirmed and state that the level of aggregate savings increases with increase in the ratio of income inequality. They also suggest that rich countries which have developed economic system involve positive relationship between savings and income inequality and this result is based on the business improvements of 2000s.

As the process is, the more we have equality in income the more changes in living standards of people and their consumption, also the rate of savings will change according to the level of equality in income. For example, as more equality in income leads to high level of consumption for the lower income class and therefore their saving rates will decline, and for middle income class less consumption and their rate of savings raise. But there is no direct relationship between income inequality and saving rate. Saving does not rely on income, if we are going to redistribute the income, aggregate saving is going to change by the influence of income inequality on the value set by the size of the income class, so if income redistributed its impact on the three income groups are: the consumption standard of high income class does not change so the rate of saving is unaffected, but it develops the middle and lower class through the changes in consumption standard. Rein Haagsma. (2018).

Piotr Misztal1 (2011), studied the relationship between economic growth and saving in different economic development and he found that there is a one positive side in a relationship between the two variables in the countries with different level of economic development; advanced, emerging and developing economies. He found that the change in the gross domestic saving "GDS" will lead to change in the gross domestic product "GDP" in a positive way. When the gross domestic saving will increase this will lead to an increase in the GDP of the country whatever is the level of economic development in it. While in the other hand the change in GDP will not lead to growth in the GDS. Also, he said that the reason behind that result is the marginal propensity to consume "MPC" is growing relatively slower than the marginal propensity to save "MPS" as the country's economic development.

Piotr also figured out in his research that national economic policy most encourages the habit of saving money because when we people save more and use our saving in an efficient way this led to an improvement in the economy at whole. In expansion, national economic specialists ought 


\section{International Journal of Social Science and Economic Research}

ISSN: $2455-8834$

Volume: 05, Issue: 07 "July 2020"

to make suitable conditions for the reallocation of national assets from conventional (nongrowth) divisions to the so-called cutting edge (growth-led) segments of the economy, fortifying economic development.

Reza Najarzadeh et al. (2014), conducted an article in Iran that study the relation between Economic growth and saving and they found that there is a positive relationship between the two variable saving and economic growth in both the short-run and long-run. And they found that Iran's government they should improve and encourage the private sector in order to raise the saving.

MihuțIoan (2015), study the impact of savings in economic growth by comparing the relationship between the saving level and the economic growth in the two countries that have experienced blasting development within the postwar period: Japan and China. And he concludes that in the two countries the high saving level lead to a production surplus. Because people have two choices to spend their income, they either consume it or save it and in the case if they save their income, they may invest it in any production investment. But there is no one to consume these products so that leads to production surplus in both countries. Secondly, high saving level helps both of the Japan and China to advance their economies at the beginning. Also, one of the results that he founded from the research paper that both of the two countries have an important liquidity as a benefit of their saving rate. And that liquidity gives them the chance to be from the strongest economies in the world. Finally, he found that the saving level in low income countries is lower than the saving level in high income countries.

CagayCoskkuner and OluseyeOlashinde-Williams (2017), study the relationship between the economic growth and saving rate in 14 developed countries and 6 developing ones to understand whom the saving level in open economy effect the economic growth and they come out with the result that there is a positive relationship between the economic growth and saving rate. And they found that saving is very important to develop the country and governments should encourage all the policies which will increase the saving rate especially in the developing country more than the developed one.

There are two positive sides in a relationship between the saving and the investment in japan Panel Narayan (2005). When saving is high, investment will be high and when there is an increase in the investment this will increase the saving level. ShimeliseHundie (2016), studied the relationship between saving, investment and economic growth in Ethiopia. He found that there is causality positive relationship between the three factors. This means that the change in savings lead to change in investment and that change will lead to change in economic growth. And he figured out that the relationships between them are two-sided. Which means economic growth will affect the investment and that will change the saving. Also, he came out with the 
result that the relationship between saving and economic growth is indirect. Following research hypothesis are developed on the literature settings:

H1: There is relationship between the socioeconomic characteristics (Gender, Age, Nationality, Education level) and income inequality.

H2: There is relationship between income inequality and saving level.

H3: There is positive relationship between saving level and economic growth.

\section{RESEARCH METHODOLOGY}

The study used primary data to achieve the objectives of the study. The survey was divided into two sections: Section A examined the socio-economic characteristics of respondents, Section B examined if respondents saved monthly, how much that portion was and in which sector they saved. Sample size is 159 respondents earning and living in UAE. Data analyzed in two steps. In the first step, descriptive analysis has been done to study the demographics the study. In the second step spearman correlation analysis and regression analysis has been done to test the relationship between the constructs and effect of socioeconomic factors on the income level, respectively.

\section{DATA ANALYSIS AND DISCUSSION}

\subsection{Descriptive Analysis:}

Frequency test used to view the demographics of the study. Following, tables shows the findings of the general information.

Table 1: General information on the respondents

\begin{tabular}{|l|l|l|l|}
\hline \multirow{5}{*}{ Gender } & & Frequency & $\%$ \\
& & & \\
\cline { 2 - 4 } & Male & 53 & 33.3 \\
\cline { 2 - 4 } & Female & 106 & 66.7 \\
\cline { 2 - 4 } & Total & 159 & 100 \\
\hline \multirow{5}{*}{ Age-group } & $18-20$ & 28 & 17.6 \\
\cline { 2 - 4 } & $21-30$ & 66 & 41.5 \\
\cline { 2 - 4 } & $31-40$ & 37 & 23.3 \\
\cline { 2 - 4 } & $41-50$ & 19 & 11.9 \\
\cline { 2 - 4 } & Above 50 & 9 & 5.6 \\
\cline { 2 - 4 } & Total & 159 & 100 \\
\hline Nationality & Local & 51 & 32.1 \\
\hline
\end{tabular}


International Journal of Social Science and Economic Research

ISSN: $2455-8834$

Volume: 05, Issue: 07 "July 2020"

\begin{tabular}{|c|c|c|c|}
\hline & Arabian & 100 & 62.9 \\
\hline & Asian ( non-Arabian) & 5 & 3.1 \\
\hline & African (non-Arabian) & 1 & 0.6 \\
\hline & European & 0 & 0 \\
\hline & Other & 2 & 1.2 \\
\hline & Total & 159 & 100 \\
\hline \multirow[t]{8}{*}{ Education level } & No formal education & 0 & 0 \\
\hline & Primary & 0 & 0 \\
\hline & Secondary School & 1 & 0.6 \\
\hline & High School & 22 & 13.8 \\
\hline & Diploma & 17 & 10.7 \\
\hline & Bachelor's Degree & 96 & 60.4 \\
\hline & $\begin{array}{l}\text { Postgraduate (Masters or Ph. } \\
\text { D. }\end{array}$ & 23 & 14.5 \\
\hline & Total & 159 & 100 \\
\hline \multirow[t]{5}{*}{ Monthly Income } & less than 15,000 & 91 & 57.2 \\
\hline & 15,000 -- 30,000 AED & 62 & 39 \\
\hline & $30,001--45,000$ AED & 5 & 3.1 \\
\hline & More than 45,000 & 1 & 0.6 \\
\hline & Total & 159 & 100 \\
\hline \multirow[t]{3}{*}{ Do you save money? } & Yes & 99 & 62.3 \\
\hline & No & 60 & 37.7 \\
\hline & Total & 159 & 100 \\
\hline \multirow{6}{*}{$\begin{array}{l}\text { If yes, how much you save } \\
\text { monthly? }\end{array}$} & less than $15 \%$ & 44 & 44.44 \\
\hline & $15 \%-30 \%$ & 40 & 40.40 \\
\hline & $31 \%--45 \%$ & 15 & 15.15 \\
\hline & $46 \%--60 \%$ & 0 & 0 \\
\hline & More than $60 \%$ & 0 & 0 \\
\hline & Total & 99 & 100 \\
\hline \multirow{5}{*}{$\begin{array}{l}\text { How do you invest your } \\
\text { saving? }\end{array}$} & Saving account & 47 & 47.47 \\
\hline & Shares, bonds,etc.. & 12 & 12.12 \\
\hline & Private Investment & 21 & 21.2 \\
\hline & Other & 19 & 19.19 \\
\hline & Total & 99 & 100 \\
\hline \multirow{7}{*}{$\begin{array}{l}\text { In which sector you invest } \\
\text { your saving? }\end{array}$} & Industry & 6 & 6.6 \\
\hline & Technology & 7 & 7.7 \\
\hline & Real estate $\&$ construction & 19 & 19.9 \\
\hline & Financial sector & 8 & 8.8 \\
\hline & Goods production & 5 & 5.5 \\
\hline & Other & 49 & 49.49 \\
\hline & Total & $\begin{array}{l}94 \_(5 \text { are } \\
\text { missing })\end{array}$ & 100 \\
\hline
\end{tabular}


As displayed in Table 1, Most of the respondents are female (66.7\%) and are in an age-group of (21-30), have bachelor's degree (60.4\%). Data in income shows that most of respondents' monthly income belongs to the range less than 15,000 Dirhams (57.2\%). About 63 percent of the respondents are Arab and about 62 percent save monthly. And the percentage of their saving was (44.4\%). Most of them invest their saving in saving accounts and (49.49\%) of respondents prefer another sector. In addition, some graphs also added to show the relationship among different constructs of the study.

Figure 1: Income, saving habit and Gender

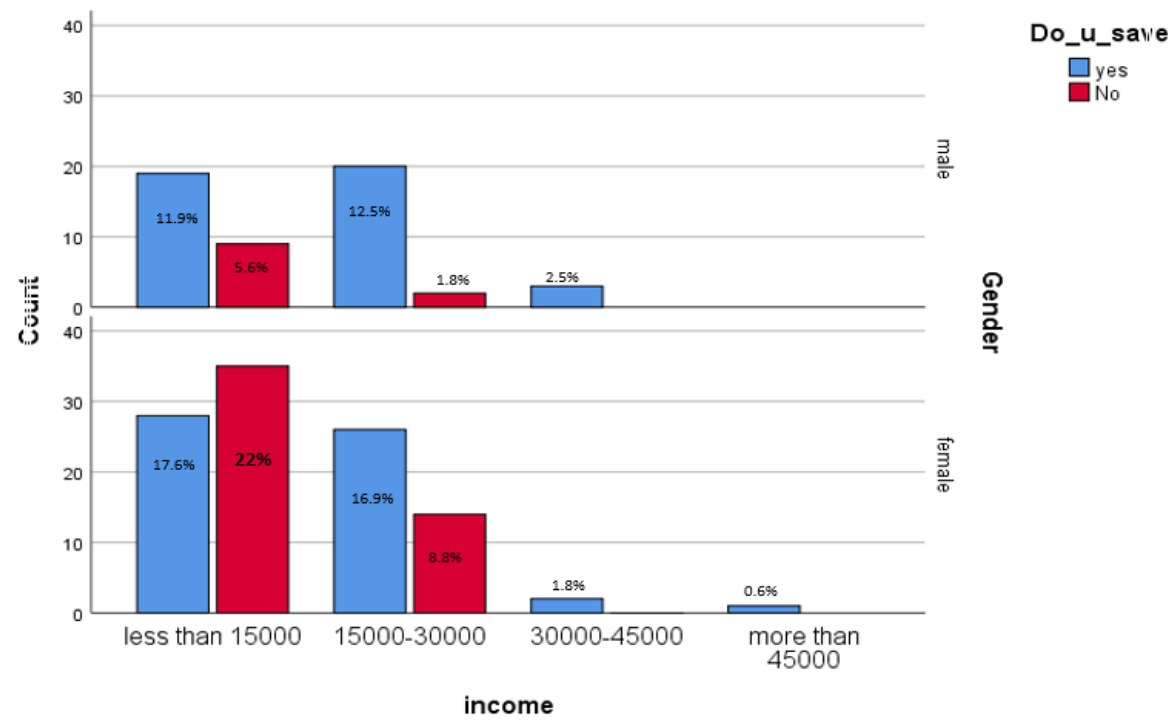

Based on the income, saving habit \& gendergraph, people saving habits vary with gender and deferent income level, $11.9 \%$ of males whose income is less than 15000 save, while $5.6 \%$ do not save. $12.5 \%$ from the same gender and the income they receive place between 15000-30000 save, but $1.8 \%$ don't save. Moreover, only $2.5 \%$ of the same gender and income of 30000 450000 save from their income. For females, it shows from graph that those whose income is less than $15000,17.6 \%$ of female save but $22 \%$ don't. Also, those who receive from 15000 $30000,16.9 \%$ of them save while $8.8 \%$ don't. Finally, only $1.8 \%$ whose income $30000-45000$ save. This chart explains that men save more than female with different income. As it showed, small percentage of male don't save in comparison to females. Also, this graph shows that there is no much difference in income between the two genders. They almost receive the same income. 
Figure 2: Income, saving habit and Age

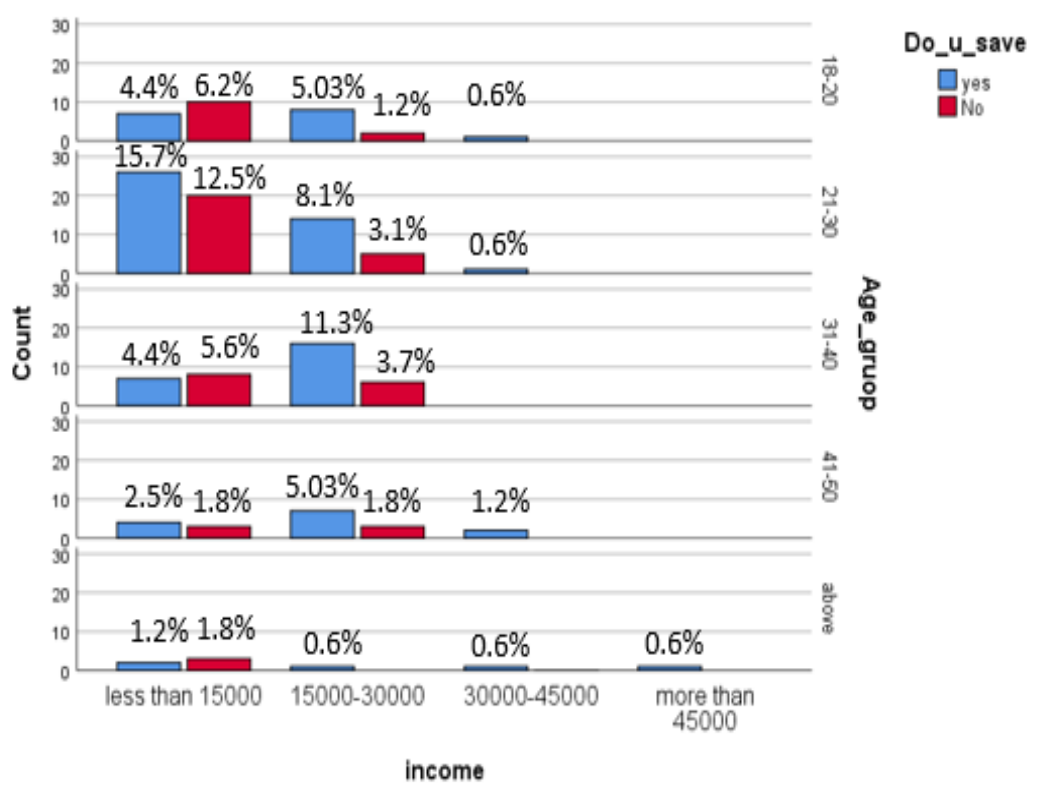

Based on the income, saving habits \& age graph, people's saving habits vary with different ages and deferent income levels, $4.4 \%$ of those whose age is from 18-20 year olds and their income is less than 15000 save, while $6.2 \%$ do not save, $5.03 \%$ of people from the same age and the income they receive is placed between 15000-30000 save from their income but $1.2 \%$ don't save, moreover only $0.6 \%$ of the same age group and whose income is 30000-45000 save from their income. The second age group is from 21-30 year olds, show that those whose income less than $15000,15.7 \%$ of them save but $12.5 \%$ don't, also those who receive from $15000-30000,8.1 \%$ of them save while $3.1 \%$ don't, finally only $0.6 \%$ whose income $30000-45000$ save. This chart explains that there is inverse relationship between people's ages and saving habits because people whose age is above 50 with different income level save less. For example, only $1.2 \%$ of people above 50 with income less than 15000 save while $4.4 \%$ of people whose ages are from 18-20 years old with same income save. Also those whose age is between 31-40 years old and their income is between 15000-30000 save more than those whose age is above 50 years old and receive same income, so as age level increases, people tend to save less. Even though, from that chart we can find that there is positive relationship between the age and income level. When people grow older, they receive more income. 


\section{International Journal of Social Science and Economic Research}

ISSN: $2455-8834$

Volume: 05, Issue: 07 "July 2020"

Figure 3: Income, saving habit and nationality

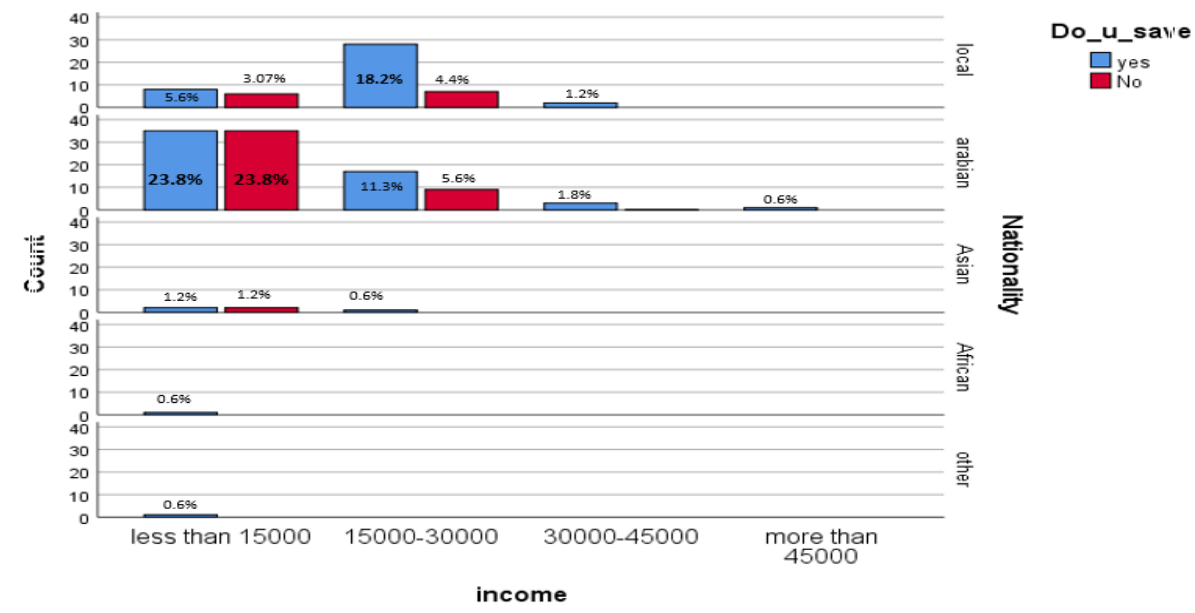

According to the figure 3 people from Arab nations with different income levels save more compared to other nations. 23.8\% of Arab people with income less than 15000 save and 23.8\% don't while $5.6 \%$ of locals from the same income can save, Asia and Africa come after with less percentages.

Arab nations with income less than 15000, the saving habits between those who save, and don't they have equal percentage but once their income increased the percentage of those who save increased compared to those who don't.

UAE locals with income $15000-30000$ save by $18.2 \%$ and $4.4 \%$ do not save. Based on the tested sample, locals tend to save as their income increases because while their income is less than 15000 those who save is $5.5 \%$ and when their income increases from 15000-30000 the amount people who save is increased to $18.2 \%$. 
International Journal of Social Science and Economic Research

ISSN: $2455-8834$

Volume: 05, Issue: 07 "July 2020"

Figure 4: Income, saving habit and education level

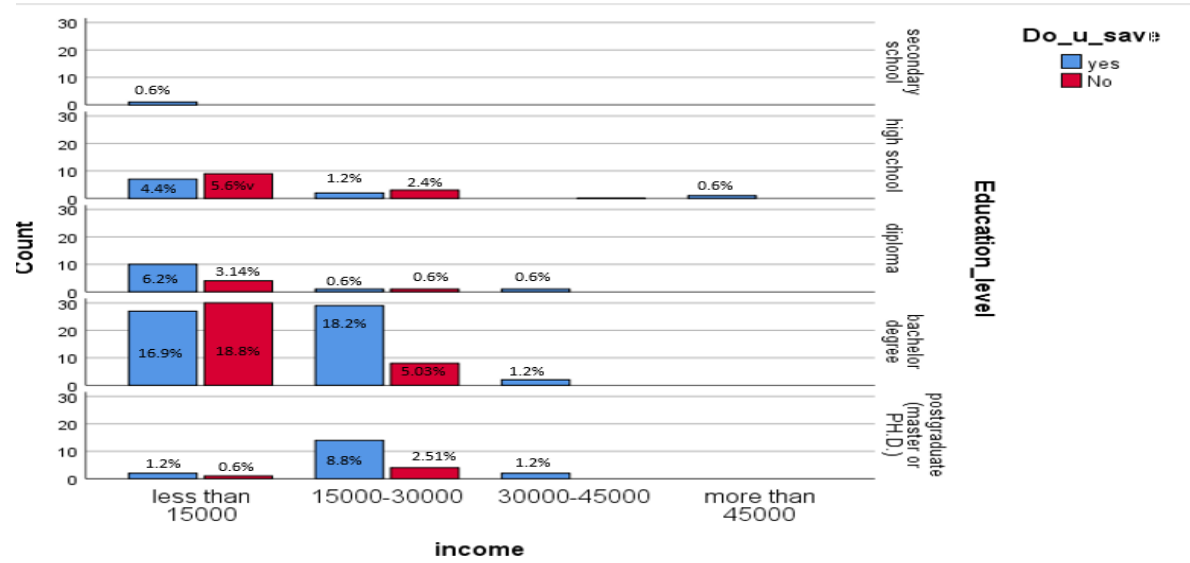

According to the above figure, generally positive relationship between education level and saving habit has been approved since people with bachelor's degree save more than those with diploma, or high school. People with diploma and income less than 15000 save by $6.2 \%$ and $3.14 \%$ don't, with income between 15000-30000 0.6\% save and 0.6\% don't save, while those with bachelor degree and income less than $1500016.9 \%$ of them save and $18.8 \%$ of them don't save, $18.2 \%$ with the same qualification and income between 15000-30000 save and only $1.2 \%$ with income between 30000-45000 save. Based on the above, more educated people get more income thus tend to save more.

Figure 5: Saving level and investment

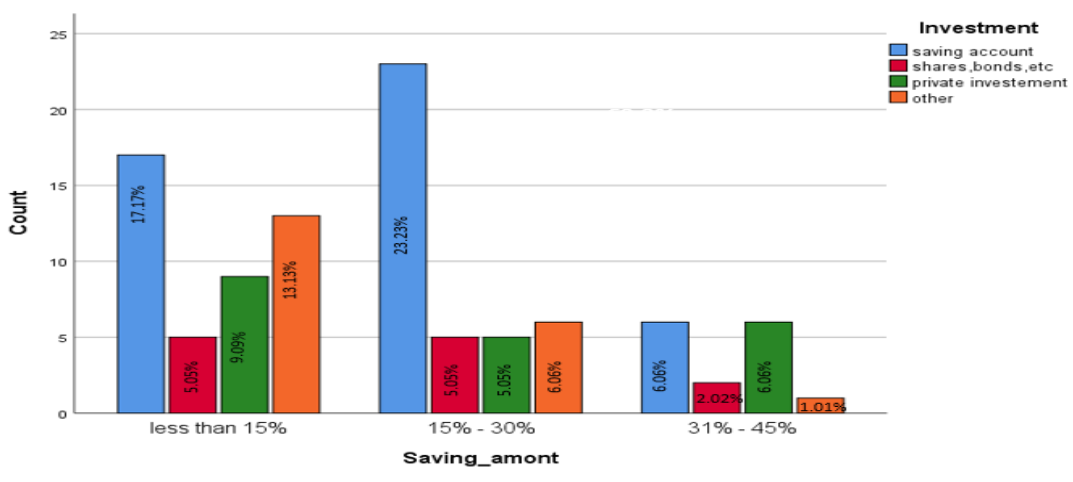

According to figure 5, saving account is the most preferred for people who save regardless the amount of their savings. $17.17 \%$ of the respondents who save less than $15 \%$ of their monthly income invest it in saving account, $23.23 \%$ of those who save between $15-30 \%$ also prefer saving account, and only $6.06 \%$ of respondents who save from $31-45 \%$ go on the same path. Most of respondents save less than $15 \%$ of their income, $17.17 \%$ of them save their money in the 
saving accounts, $5.05 \%$ in shares and bonds, $9.09 \%$ in private investment, and $13.13 \%$ answered that they may invest their saving to educate their child, family business, or because most of UAE residents are foreigners they may send their saving to their home country.

\section{Figure 6: investment and Sector}

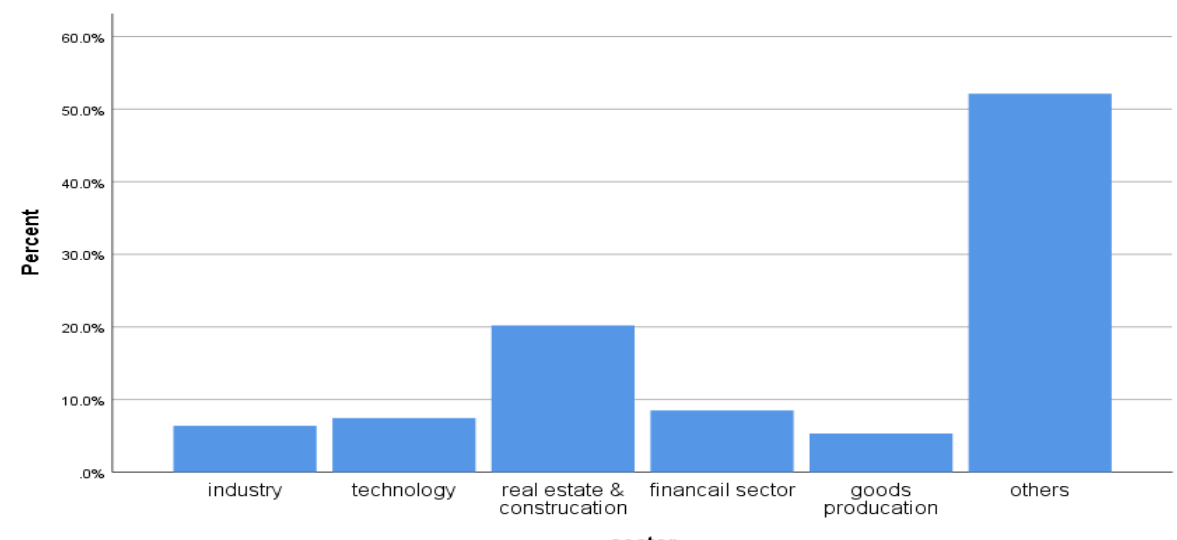

This graph shows that UAE savers invest their savings in many sectors for example as most of the residents are foreigners they would send their money back to their home country with around $53 \%$, then gradually other groups invest in real estate and construction sector by $20 \%$, financial sector $9 \%$, technology $8 \%$, industry $7 \%$ and goods production by $5 \%$.

\subsection{Correlation:}

We used Spearman correlation analysis to measure the relationship between the income level and socioeconomic factors. The findings are displayed in the table below:

Table 2: Correlation

\begin{tabular}{|l|c|}
\hline \multicolumn{1}{|c|}{ Socioeconomic Factors } & $\begin{array}{l}\text { Income } \\
\text { Level }\end{array}$ \\
\hline Income & 1 \\
\hline Gender & -0.071 \\
\hline Age & $.199^{*}$ \\
\hline Nationality & -0.395 \\
\hline & \\
\hline Education level & $0.346^{* *}$ \\
\hline
\end{tabular}




\section{International Journal of Social Science and Economic Research}

ISSN: $2455-8834$

Volume: 05, Issue: 07 "July 2020"

Table 2 shows gender has a -0.071 correlation with income. P-value also confirms insignificant relationship between gender and income level.

Age-group has a 0.199 correlation with income, which means, there is a positive correlation between age-group and income. When the age increases, the income will increase as well. Therefore, the relationship between age-group and income is low. Nationality has a -0.395 correlation with income. Education level has 0.346 correlation with income. That means, there is a positive correlation between education level and income.

Literature supported that income level positively related with saving or saving behavior. According to the harrod -domar model which proposed that the rate of saving could be used as standard to judge the economic growth rate.

First, saving account comes as the most preferred option for UAE residents to save their money. As more people invest their money in saving accounts, more capital will be available for investors. If money is deposited into a saving account in a bank, the bank is going to use that money to lend investors to start up their business. If company $\mathrm{X}$, as an example, wants to build a new factory. It is going to borrow from the bank and as the factory operate company output would increase, more revenues will be provided to construction companies and equipment suppliers and more jobs will be created in the society leading to economic growth.

Second, according to the results that have been collected through our survey we have noticed that regardless the amount of saving, the money that have been put aside from people income is sent to abroad as most of the UAE residents are foreigners. The UAE estimated population of 2019 is $9,819,302$ taking into the consideration that $90 \%$ of the population are immigrants. Edrees. A (2016) reveal that foreign workers play an important role in economic growth and activity improvement of United Arab Emirates, on the other hand he concluded that outflow remittance harms the economic growth of the countries as its negative significant impact on economic growth and it improves finance and back up for received country. However, the negative impact is appearing in short-run rather than in long-run economy.

Third, private investment option come after saving account for people who save in UAE. Private investment does not mean saving account in a bank rather is the purchase of an asset that is likely to generate income, has value and is not easy to sell such as building new factories, buying machines, and buying robots to make automation possible. Although public investment has an impact on the level of economy, private investment performs better and has more significant role on the economy, but public investment has positive indirect impact on the economy. Reinhart. R, and khan M. (1989). As investment, aggregate demand will raise since investment is one of its components, as $\mathrm{AD}$ raise, short run economic growth exists. $\mathrm{AD}$ consists of other components too to affect the economy, for example, if consumer spending is declined or there is a fall in 


\section{International Journal of Social Science and Economic Research}

ISSN: $2455-8834$

Volume: 05, Issue: 07 "July 2020"

exports, then investment may not lead to higher $\mathrm{AD}$ and then raise the economic level. Private investment is the key driven of economic growth since it makes more employment, generate funds, build competition and make more innovation - which all are the essential tools for growth.

Fourth, financial market took the last place among the options to invest the money in. Financial market plays a very significant role to support the efficiency and effectiveness of the economy. Strong positive relationship has been approved between financial market and economic growth. For example, if a new coffee company is going to advertise itself to big investors, and if investors think the company is a good idea, they will invest in it and sponsor it and this will launch it to the official company market where any company or individual who believe in the profitability of the coffee company may buy its stocks which will make them partial owners. Their investment will help the company grow and become more successful as more buyers would buy its stocks so the stock demand will increase and more company value would be created which will lead to more output, more jobs available and more market improvement. Financial market such as stock and bonds manage in the most efficient way. People's savings and investments also direct them in a way that smooths the accumulated capital and goods and services production.

Also, according to our analysis we found that most of the respondents choose not to invest in any of UAE economic sectors because as mentioned above most of UAE resident are foreigners and they send their savings to their home country, and some answered that they save their money for their child education and those may include in education economic sector.

\section{CONCLUSION}

This research tried to find the socioeconomic characteristics that affect most income inequality in UAE and the relationship between income inequality and economic growth through saving level. The findings show that all socioeconomics characteristics affect income inequality exception gender because is not significant factor. Age and education level have positive relationship with income, but education is affected more than age which prove through the equation. While nationality has negative relationship with income at the same time it's the most significant effect factor. Locals have more income while non-local have less income. Therefore, people with high income tend to save more. So, we found that there is income inequality in UAE thus good for saving level as well as affect the economic growth positively. In addition to that, $90 \%$ of UAE population is non-local. They receive $62.89 \%$ from total income and save $54 \%$. While local receive about $32 \%$ from total income and save $78.1 \%$. So, non-local is save less than local because their income is less in comparing to local people. 
International Journal of Social Science and Economic Research

ISSN: $2455-8834$

Volume: 05, Issue: 07 "July 2020"

Researchers recommend the upcoming researchers to expand the sample size to get more generalized results. More opinion from different respondent can improve the findings of the research. Further, new researchers can add some other independent constructs to study. Also, we think that the government should relax the investment policies for the foreigners and should reduce the constraints and regulations for the people to enhance the investments in the country and to increase the GDP of UAE, ultimately.

\section{REFERENCES}

1. Gallo, C. (2002). Economic growth and income inequality, theoretical background and empirical evidence, London: Development Planning Unit, University College London.

2. Keeley, B. (2015). Income Inequality: The Gap between Rich and Poor. Paris: OECD

3. Haagsma, R. (2018). Income inequality and saving in a class society: the role of ordinal status, Economics: The Open-Access, Open-Assessment E-Journal, 12 (2018-46): 1-30

4. Koo, J ., \& Song, Y. (2016). The relationship between income inequality and aggregate saving: an empirical analysis using cross-country panel data, Applied Economics, 48(10), 892-901.

5. Charles-Coll, J. (2011). Understanding income inequality : concept, causes and measurement, International Journal of Economics and Management Sciences, 1(3), 1728.

6. Narayan, P. K. (2005). The relationship between saving and investment for Japan, Japan and the World Economy, 17(3), 293-309.

7. COSKUNER, C. (2017). The Impact of Saving Rates on Economic Growth in an Open Economy, International Journal of Economic Perspectives, 11(4), 70-80.

8. loan, M. M. (2015). The Impact of Savings in Economic Growth. Comparative Study Between Japan and China, Economic Sciences Series , (1), 295-298.

9. Misztal, P. (2011). the relationship between savings and economic growth in countries with different level of economic development, Financial Internet Quarterly, 17-29.

10. Hundie,K.S.(2016.). Saving, investment and economic growth in Ethiopia, Lap Lambeart Academic.

11. Najarzadeh, R., Reed, M., \&Tasan, M. (2014). Relationship between Savings and Economic Growth: The Case for Iran. Journal of International Business and Economics, 2(4), 107-124.

12. Nolan, B., Richiardi, M. G., \& Valenzuela, L. (2019). The Drivers of Income Inequality In Rich Countries, Journal of Economic Surveys, 33(4), 1285-1324.

13. Furceri, D. \&Ostry, J. (2019). Robust determinants of income inequality, Oxford Review of Economic Policy, 35(3), 490-517. 
14. Keller, K. (2010). how can education policy improve income distribution? an empirical analysis of education stages and measures on income inequality, Journal of Developing Areas, 43(2), 51-77.

15. Alan, S. Atalay, K. \& Crossley, T. (2015). do the rich save more? evidence from canada, Review of Income \&Wealth, 61(4), 739-758.

16. Alvarez-Cuadrado, F. \& El-Attar Vilalta, M. (2018). Income Inequality and Saving, Oxford Bulletin of Economics \& Statistics, 80(6), 1029-1061.

17. http://worldpopulationreview.com/countries/united-arab-emirates-population/

18. Carmen, R. and Mohsin, K. (1990). Private Investment and Economic Growth in Developing Countries, world development, 89(60), 19-27.

19. Edrees A (2016). The Impact of Foreign Workers, Outflow Remittances on Economic Growth in Selected GCC Countries: ARDL Approach, Arabian J Bus Manag Review, $6(5)$. 